\section{HEOEBVI \\ Ano 27 ? \\ OSTI}

COMPARISON OF SW-846 METHOD

3051 AND SW-846 METHOD

7471 A FOR THE PREPARATION OF

SOLID WASTE SAMPLES FOR

MERCURY DETERMINATION
J. M. GIAQUINTO

A. A. ESSLING

J. M. KELLER
IUYLEED AMD OPERATED BY LOCKHEEO MIMATK ENERGY RESEARCH CORPORAMOI FOB THEULTED STLTES

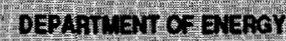


This report has been reproduced directly from the best available copy.

Available to DOE and DOE contractors from the Office of Scientific and Technical Information, P. O. Box 62, Oak Ridge, TN 37831; prices available from (423) 576-8401, FTS 626-8401.

Available to the public from the National Technical Information Service, U.S. Department of Commerce, 5285 Port Royal Road, Springfield, VA 22161.

This report was prepared as an account of work sponsored by an agency of the United States Government. Neither the United States Government nor any agency thereof, nor any of their employees, makes any warranty, express or implied, or assumes any legal liability or responsibility for the accuracy, completeness, or usefulness of any information, apparatus, product, or process disclosed, or represents that its use would not infringe privately owned rights. Reference herein to any specific commercial product, process, or service by trade name, trademark, manufacturer, or otherwise, does not necessarily constitute or imply its endorsement, recommendation, or favoring by the United States Government or any agency thereof. The views and opinions of authors expressed herein do not necessarily state or reflect those of the United States Government of any agency thereof. 


\title{
Comparison of SW-846 Method 3051 and SW-846 Method 7471A for the Preparation of Solid Waste Samples for Mercury Determination
}

\author{
J. M. Giaquinto \\ A. M. Essling* \\ J. M. Keller \\ *Analytical Chemistry Laboratory, Argonne National Laboratory \\ Prepared by \\ OAK RIDGE NATIONAL LABORATORY \\ Oak Ridge, Tennessee 37831 \\ managed by \\ LOCKHEED MARTIN ENERGY RESEARCH CORP. \\ for the \\ U. S. DEPARTMENT OF ENERGY \\ under contract \\ DE-AC05-96OR22464
}




\section{DISCLAIMER}

Portions of this document may be illegible in electronic image products. Images are produced from the best available original document. 


\section{CONTENTS}

\section{Page}

LIST OF TABLES $\ldots \ldots \ldots \ldots \ldots \ldots \ldots \ldots \ldots \ldots \ldots \ldots \ldots \ldots \ldots$ iv

ACRONYMS AND INITIALISMS $\ldots \ldots \ldots \ldots \ldots \ldots \ldots \ldots \ldots \ldots$

ACKNOWLEDGMENTS $\ldots \ldots \ldots \ldots \ldots \ldots \ldots \ldots \ldots \ldots \ldots \ldots$ vi

ABSTRACT $\ldots \ldots \ldots \ldots \ldots \ldots \ldots \ldots \ldots \ldots \ldots \ldots$ vii

1. INTRODUCTION $\ldots \ldots \ldots \ldots \ldots \ldots \ldots \ldots \ldots \ldots \ldots \ldots$

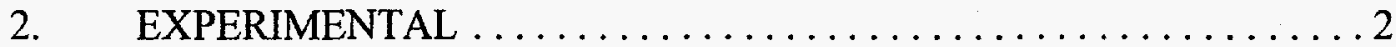

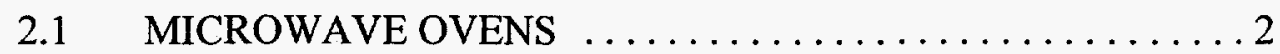

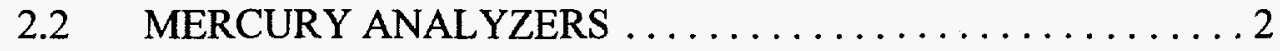

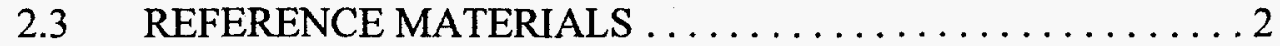

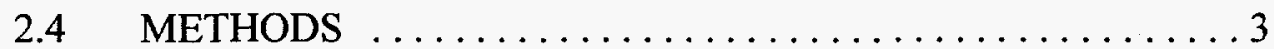

3. RESULTS AND DISCUSSION $\ldots \ldots \ldots \ldots \ldots \ldots \ldots \ldots$

4. REFERENCES $\ldots \ldots \ldots \ldots \ldots \ldots \ldots \ldots \ldots$

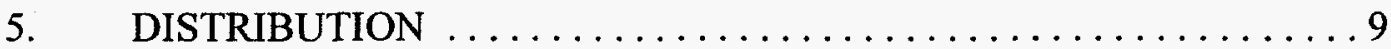




\section{LIST OF TABLES}

Table 1-4 Buffalo River Sediment Results $\ldots \ldots \ldots \ldots \ldots \ldots \ldots$

$5-8$

$9-12$

13-16
Coal Fly Ash Results

Sewage Sludge Results

Mercury in Oil Results
Page 7 8 


\section{ACRONYMS AND INITIALISMS}

ANL

CVAA

GFAA

ICP-AES

ICP-MS

ORNL

QAPjP

RMAL

SRM

TRU

TWCP

WIPP
Argonne National Laboratory

Cold Vapor Atomic Absorption

Graphite Furnace Atomic Absorption

Inductively Coupled Plasma Atomic Emission Spectrum

Inductively Coupled Plasma Mass Spectrometry

Oak Ridge National Laboratory

Quality Assurance Project Plan

Radioactive Materials Analytical Laboratory

Standard Reference Material

Transuranic

Transuranic Waste Characterization Program

Waste Isolation Pilot Plant 


\section{ACKNOWLEDGMENTS}

The authors wish to acknowledge the following people for their important contributions which made this study possible.

Fox, Irene, Scientific Associate, Analytical Chemistry Laboratory, ANL. Assisted in standard preparation and analysis.

Groeyzk, Don, Chemist, Analytical Chemistry Laboratory, ANL. Assisted in the planning and coordination of the work between ORNL \& ANL.

Hagerman, Kathy, Senior Office Assistant, Chemical and Analytical Sciences Division, ORNL. Secretarial duties and final drafting of report.

Huff, Doris, Scientific Associate, Analytical Chemistry Laboratory, ANL. Assisted in standard preparation and analysis.

Ross, Tobin, Chemist, Chemical and Analytical Sciences Division, ORNL. Assisted in standard preparation and analysis.

Vinokanr, Elena, Special Team Appointee, Analytical Chemistry Laboratory, ANL. Assisted in standard preparation and analysis. 


\begin{abstract}
This report describes experimental studies to evaluate the use of EPA SW-846 method 3051 for the preparation and dissolution of solid samples for mercury analysis. The study showed that the method is effective in the dissolution of four sample types without significant loss of mercury. Based on the results of this study, method 3051 was used for analysis of high radioactive waste samples to obtain results for a number of RCRA regulated metals without the need to utilize a separate sample preparation method (EPA SW-846 method 7471A) specific only for mercury.
\end{abstract}




\section{INTRODUCTION}

The Radioactive Materials Analytical Laboratory (RMAL) located at Oak Ridge National Laboratory (ORNL) is participating in the characterization of transuranic waste targeted for the national Waste Isolation Pilot Plant (WIPP) in Carlsbad, New Mexico. The waste streams contain high concentrations of alpha emitting radionuclides and therefore all raw sample handling and preparations require alpha containment (radiochemical hoods, gloveboxes, or hotcells). To reduce the risk from sample exposure and increase sample throughput, it was beneficial to prepare for all metal analysis (ICP-AES, ICP-MS, GFAA, and CVAA) in a single digestion with a minimal amount of sample handling. SW846 method 3051 (Microwave Assisted Acid Digestion of Sediments, Sludges, Soils, and Oils) is ideal for this situation. The use of this preparation method would allow for a single fast and efficient digestion for all metals targeted by the WIPP program.

The recent update (Update II) to SW-846 includes an approved method 3051 for the preparation of samples for metals analysis for techniques such as ICP-AES, ICP-MS, and GFAA, but does not include mercury analysis by CVAA. Also, SW-846 method 7471 A (Mercury in Solid or Semisolid Waste (Manual Cold-Vapor Technique) does not allow for alternative preparation methods. As part of the WIPP Transuranic Waste Characterization Program the RMAL investigated in collaboration with the Analytical Chemistry Laboratory, located at Argonne National Laboratory, the feasibility of microwave digestion for mercury determination by cold vapor atomic absorption.

For this study four standard reference materials (SRM) were used to cover the range of matrices and mercury levels that most likely would be encountered during the sampling and characterization program. The laboratories independently prepared each SRM in batches of five and analyzed the digestates using method 7471A. For the microwave preparations each SRM batch was digested using three different microwave ovens (one pressure controlled, one temperature controlled, and one high pressure oven that was temperature controlled) using the pressure/temperature profiles specified in method 3051. A conventional water bath preparation as specified in method $7471 \mathrm{~A}$ was also included.

This report presents the results of this study and examines how each method compared to the acceptance criteria established in the WIPP TWCP Quality Assurance Plan. 


\section{EXPERIMENTAL}

\subsection{MICROWAVE OVENS}

Oak Ridge National Laboratory performed microwave digestions using a CEM MDS 81 microwave oven with pressure control and a Milestone MEGA 1200 microwave with internal temperature control. Argonne National Laboratory used a CEM MDS 2100 microwave oven with temperature and pressure control.

The CEM MDS 81 is a 600 watt unit employing lined digestion vessels. The liners are made of PFA teflon ${ }^{\boxplus}$ and the vessel body made of Ultem ${ }^{\oplus}$ polyetherimide. These vessels can operate with internal pressures up to $190 \mathrm{psi}$. The Milestone oven is a 1000 watt unit employing TFM ${ }^{\text {tm }}$ vessels with HTC liners capable of handling digestion pressures up to 1500 psi. The CEM MDS 2100 is a 1000 watt unit employing heavy duty vessels constructed of liners made of TFM ${ }^{\text {tm }}$, sleeves of PFA teflon $^{\circledR}$, fiber glass and Ultem, and bodies of polypropylene. These vessels have operating pressures of $600 \mathrm{psi}$.

\subsection{MERCURY ANALYZERS}

Oak Ridge National Laboratory performed all mercury analysis on a Thermo Jarrell Ash QS-1 cold vapor mercury analyzer. Argonne National Laboratory performed all mercury analysis on a Leeman Labs PS 200 cold vapor mercury analyzer. Both analyzers employ flow injection and a 5\% stannous chloride solution to reduce the mercury. The mercury vapor produced is dried and then carried to an absorption cell. The analytical wavelength used was $253.7 \mathrm{~nm}$.

\subsection{REFERENCE MATERIALS}

The WIPP samples consist mainly of inorganic or organic radioactive contaminated sludges that have been mixed in cement. No reference material with a certified level of mercury that matched the WIPP sample matrices was available, however, if mercury was recovered in the more difficult standards covering a wide range of silicate concentrations ( $>50 \%$ in SRM 2704, $>60 \%$ in SRM $1633 \mathrm{a} / \mathrm{b}$, and about 20 $\%$ in the sewage sludge) and mercury levels, this would demonstrate the ability to recover the mercury in the WIPP samples. Some of the wastes contain oil, so an oil reference material was also used in the validation process. The standards selected were:

- NIST Buffalo River Sediment (SRM 2704)

- NIST Coal Fly Ash (SRM 1633a/b)

- Environmental Resource Associates Sewage Sludge (WW-26 lot\#2612)

- Conostan 100 ppm mercury in oil (lot\#13015) 


\section{$2.4 \quad$ METHODS}

For the sample preparations following method 3051 protocol, standards were digested in batches of five using $0.5 \mathrm{~g}$ sample sizes $(0.25 \mathrm{~g}$ for the oil) with one blank. The blank not only served as a check for cross-contamination but also rounded each batch to six and served to obtain the recommended energy balance specified in method 3051. The microwave oven without internal temperature monitoring (CEM MDS 81) was operated at the recommended power level of 574 watts for ten minutes for each digestion batch. The microwaves with internal temperature monitoring (Milestone MEGA 1200 and CEM MDS 2100), the units were programmed to raise the internal temperature to $175^{\circ} \mathrm{C}$ in 5.5 mins and hold it at $175^{\circ} \mathrm{C}$ for the remainder of the ten minute digestion in accordance with the method. All digestions were diluted to a known volumes with reagent grade water. Sediment not dissolved by the procedure was allowed to settle prior to analysis.

Sample preparations following method 7471A protocol, reference materials were also digested in batches of five with one blank. The sample portions used were 0.2 $\mathrm{g}$ as specified in the method.

Prior to analysis, a $5 \%$ potassium permangante solution was added to all microwave digestate aliquots drop-wise until there was a persistent purple tint. This addition ensures that the mercury in solution is stabilized and would not be lost during analysis. Past experience has shown that if the potassium permangante solution is not added to the microwave digestions until a persistent purple tint develops then mercury could be lost resulting in poor recoveries.

\section{RESULTS AND DISCUSSION}

Each of the four SRM's used for this study were digested in batches of five using three different microwave ovens and one conventional water bath preparation. Two of the microwave ovens were located at the Radioactive Materials Analytical Laboratory at Oak Ridge National Laboratory while the third microwave and all waterbath preparations were performed by the Analytical Chemistry Laboratory at Argonne National Laboratory. Therefore each standard underwent four independent sample preparations with five replicates per preparation for a total of 20 replicates being analyzed for mercury. Each microwave oven was operated by an independent chemist and all waterbath preparations were performed by a single laboratory technician.

The results of each batch are shown in Tables 1-16. These results are listed by SRM showing the preparation location, preparation method, and microwave unit (if appropriate). Each replicate result is shown including the grand average for the batch. 
Each sample replicate was analyzed over three integrations. The "Experimental Value" is the average of the three integrations corrected for all dilutions. The "Standard Deviation" is the standard deviation of the three integrations and is also corrected for any dilutions performed on the replicate. The "Percent Recovery of Certified Value" is calculated as the experimental value divided by the certified value multiplied by one hundred. The TWCP acceptance criteria for mercury recovery is set at $80 \%$ - 120\% per the Quality Assurance Program Plan (QAPP). The certified value for each reference material is given below the tables along with the cold vapor analyzer used for the analysis.

Mercury concentration was determined on a total of eighty digestions. Of these, sixty were prepared in accordance with the protocol established in method 3051 and twenty were prepared in accordance with method 7471A protocol. Of those eighty digestions only three did not meet the TWCP acceptance criteria of $80 \%-120 \%$ recovery. The three outliers consisted of one Buffalo River Sediment microwave digestion with $122 \%$ of the certified value, one Sewage Sludge microwave digestion with $122 \%$ of the certified value, and one Sewage Sludge microwave digestion with $77 \%$ of the certified value. All of the outliers were samples prepared and analyzed at ORNL. It is believed that these outliers were due to problems experienced with the Thermo Jarrell Ash QS-1 mercury analyzer and not with the preparation method. This instrument was recently purchased and drifting of the baseline was a noted problem during the initial setup and test period of the unit.

This validation study has shown method 3051 to be a viable method for the preparation of solid samples for mercury determination by cold-vapor. Method 3051 is ideally suited for the preparation of radioactive waste samples. Not only can all metals be prepared with a single quick and efficient digestion using this method, but also most radiochemistry analysis can be pulled from the same preparation aliquot.

The majority of a high level radioactive laboratory technician's exposure results from having to handle raw sample during the it's preparation. Method 3051 allows for a small sample size and does away with having to perform multiple preparations and having to handle a highly radioactive waste more times than necessary. All these factors result in less personnel exposure. 


\section{Buffalo River Sediment Results (SRM2704)}

\section{Oak Ridge National Laboratory}

Table 1

Method 3051 temperature controlled digestion

Milestone MEGA 1200 microwave

Replicate Experimental Standard Peroent Recovery Number Value $(\mathrm{mg} / \mathrm{Kg})$ Deviation of Certified Value

\begin{tabular}{cccc}
\hline 1 & 1.54 & 0.005 & $105 \%$ \\
2 & 1.80 & 0.001 & $122 \%$ \\
3 & 1.52 & 0.005 & $104 \%$ \\
4 & 1.68 & 0.004 & $114 \%$ \\
5 & 1.52 & 0.002 & $104 \%$ \\
Average & 1.61 & 0.121 & $110 \%$ \\
Blank & 0.00 & 0.000 & \\
\hline - Certified Value (mg/Kg): & 1.47 & $+/-0.07$ \\
- Digestions amalyzed with a TJA QS-1 mercury \\
analyzer
\end{tabular}

\section{Argonne National Laboratory}

Table 3

Method 3051 temp/press controlled digestion CEMMDS 2100 microwave
Replicate Experimental Standard Peroent Recovery Number Value $(\mathrm{mg} / \mathrm{Kg})$ Deviation of Certified Value

\begin{tabular}{cccc}
\multicolumn{4}{c}{ CEMMDS 2100 microwave } \\
\hline Replicate & $\begin{array}{c}\text { Experimental } \\
\text { Number }\end{array}$ & $\begin{array}{c}\text { Standard } \\
\text { Valug/Kg) }\end{array}$ & $\begin{array}{c}\text { Peroent Recovery } \\
\text { Deviation }\end{array}$ \\
& & & \\
\hline 1 & 1.44 & 0.124 & $98 \%$ \\
2 & 1.49 & 0.082 & $101 \%$ \\
3 & 1.47 & 0.100 & $100 \%$ \\
4 & 1.48 & 0.113 & $101 \%$ \\
5 & 1.49 & 0.116 & $101 \%$ \\
Average & 1.47 & 0.022 & $100 \%$ \\
Blank & 0.00 & 0.007 & \\
\hline - Certified Value (mg/Kg): & $1.47 \quad+/-0.07$ \\
- Digestions analyzed with a Leeman Labs PS 200 \\
mercury analyzer
\end{tabular}

Table 2

Method 3051 pressure controlled digestion using a CEMMDS81 microwave

Replicate Experimental Standard Peroent Recovery Number Value $(\mathrm{mg} / \mathrm{Kg})$ Deviation of Certified Value

\begin{tabular}{cccc}
\hline 1 & 1.42 & 0.002 & $96 \%$ \\
2 & 1.45 & 0.002 & $99 \%$ \\
3 & 1.45 & 0.001 & $99 \%$ \\
4 & 1.43 & 0.002 & $97 \%$ \\
5 & 1.54 & 0.001 & $105 \%$ \\
Average & $\mathbf{1 . 4 6}$ & $\mathbf{0 . 0 5 0}$ & $\mathbf{9 9 \%}$ \\
Blank & 0.00 & 0.000 & \\
\hline - Certified Value (mg/Kg): & 1.47 & +-0.07 \\
- Digestions analyzed with a TJA QS-1 mercury \\
analyzer
\end{tabular}

Table 4

Method 7471 water bath digestion

\begin{tabular}{cccc}
$\begin{array}{c}\text { Replicate } \\
\text { Number }\end{array}$ & $\begin{array}{c}\text { Experimental } \\
\text { Value }(\mathrm{mg} / \mathrm{Kg})\end{array}$ & $\begin{array}{c}\text { Standard } \\
\text { Deviation }\end{array}$ & $\begin{array}{c}\text { Percent Recovery } \\
\text { of Certified Value }\end{array}$ \\
\hline 1 & 1.37 & 0.030 & $93 \%$ \\
2 & 1.41 & 0.012 & $96 \%$ \\
3 & 1.44 & 0.057 & $98 \%$ \\
4 & 1.43 & 0.061 & $97 \%$ \\
5 & 1.45 & 0.060 & $99 \%$ \\
Average & 1.42 & 0.032 & $97 \%$ \\
Blank & -0.01 & 0.016 & \\
\hline - Certified Value (mg/Kg): & $1.47 \quad+/-0.07$ \\
- Digestions analyzed with a Lerman Labs PS 200 \\
merary analyzer
\end{tabular}




\title{
Coal Fly Ash Results (SRM 1633a/b)
}

\author{
Oak Ridge National Laboratory
}

Table 5

Method 3051 temperature controlled digestion

Milestone MFGA 1200 microwave

Replicate Experimental Standard Percent Recovery Number Value $(\mathrm{mg} / \mathrm{Kg})$ Deviation of Certified Value

\begin{tabular}{cccc}
\hline 1 & 0.157 & 0.0001 & $111 \%$ \\
2 & 0.154 & 0.0002 & $109 \%$ \\
3 & 0.169 & 0.0002 & $120 \%$ \\
4 & 0.152 & 0.0001 & $108 \%$ \\
5 & 0.153 & 0.0000 & $108 \%$ \\
Average & $\mathbf{0 . 1 5 7}$ & $\mathbf{0 . 0 0 7 1}$ & $111 \%$ \\
Blark & 0.012 & 0.0002 & \\
\hline -Certified Value (mg/Kg): & 0.141 & $+1-0.019$ \\
- Digestions analyzed with a TJA QS-1 mercury \\
analyzer
\end{tabular}

Argonne National Laboratory

Table. 7

Method 3051 temp/press controlled digestion CEMMDS2100 microwave

Replicate Experimental Standard Percent Recovery Number Value $(\mathrm{mg} / \mathrm{Kg})$ Deviation of Certified Value

\begin{tabular}{cccc}
\hline 1 & 0.174 & 0.0017 & $109 \%$ \\
2 & 0.175 & 0.0015 & $110 \%$ \\
3 & 0.173 & 0.0030 & $108 \%$ \\
4 & 0.171 & 0.0006 & $107 \%$ \\
5 & 0.173 & 0.0025 & $108 \%$ \\
Average & 0.173 & 0.0015 & $108 \%$ \\
Blank & 0.000 & 0.0010 & \\
\hline \multicolumn{7}{l}{ Certified Value (mg/Kg): } & 0.16 & $+1-0.01$ \\
- Digestions analyzed with a Leeman Labs PS 200 \\
mercary analyzer
\end{tabular}

Table 6

Method 3051 pressure controlled digestion using a CEMMDS81 microwave

Replicate Experimental Standard Percent Recovery Number Value (mg/Kg) Deviation of Certified Value

\begin{tabular}{cccc}
\hline 1 & 0.132 & 0.000 & $94 \%$ \\
2 & 0.138 & 0.000 & $98 \%$ \\
3 & 0.135 & 0.000 & $96 \%$ \\
4 & 0.134 & 0.001 & $95 \%$ \\
5 & 0.152 & 0.000 & $107 \%$ \\
Average & $\mathbf{0 . 1 3 8}$ & $\mathbf{0 . 0 0 8}$ & $98 \%$ \\
Blank & 0.008 & 0.000 & \\
\hline - Certified Value (mg/Kg): & 0.141 & $+\mathrm{H}-0.019$ \\
- Digestions analyzod with a TJA QS-1 mercury \\
analyzer
\end{tabular}




\section{Sewage Sludge Results (WWS-26)}

(Purchased from Environmental Resource Associates (Lot \# 2612))

\section{Oak Ridge National Laboratory}

Table 9

Method 3051 temperature controlled digestion Milestone MEGA 1260 microwave

Replicate Experimental Standard Percent Recovery Number Value (mg/Kg) Deviation of Certified Value

\begin{tabular}{cccc}
\hline 1 & 75.3 & 0.24 & $107 \%$ \\
2 & 72.7 & 0.02 & $104 \%$ \\
3 & 75.0 & 0.11 & $107 \%$ \\
4 & 76.5 & 0.11 & $109 \%$ \\
5 & 75.9 & 0.06 & $108 \%$ \\
Average & 75.1 & 1.44 & $107 \%$ \\
Blank & 0.00 & 0.000 & \\
\hline - Certified Value (mg/Kg): & 70.2 \\
- Advisory Range: & $44.9-100$ \\
- Digestions analyzod with a TJA QS-1 mercury \\
analyzer
\end{tabular}

Table 10

Method 3051 pressure controlled digestion using a CEM MIDS81 microwave

Replicate Experimental Standand Percent Recovery Number Value $(\mathrm{mg} / \mathrm{Kg})$ Deviation of Certified Value

\begin{tabular}{cccc}
\hline 1 & 81.1 & 0.12 & $116 \%$ \\
2 & 81.0 & 0.03 & $115 \%$ \\
3 & 81.3 & 0.00 & $116 \%$ \\
4 & 82.7 & 0.08 & $118 \%$ \\
5 & 85.6 & 0.10 & $122 \%$ \\
Average & $\mathbf{8 2 3}$ & 1.93 & $117 \%$ \\
Blank & 0.00 & 0.001 & \\
\hline - Certified Value (mg/Kg): & 70.2 \\
- Advisory Range: & $44.9-100$ \\
- Digestions analyzed with a TJA QS-1 mercury \\
analyzer
\end{tabular}

Argonne National Laboratory

Table 11

Method 3951 temp/press controlled digestion CEMMDS 2100 microwave

Replicate Experimental Standard Percent Recovery Number Value $(\mathrm{mg} / \mathrm{Kg})$ Deviation of Certified Value

\begin{tabular}{cccc}
\hline 1 & 54.3 & 4.49 & $77 \%$ \\
2 & 74.5 & 4.56 & $106 \%$ \\
3 & 73.7 & 3.63 & $105 \%$ \\
4 & 73.6 & 4.04 & $105 \%$ \\
5 & 74.2 & 2.98 & $106 \%$ \\
Average & 70.1 & $\mathbf{8 . 8 2}$ & $\mathbf{1 0 0 \%}$ \\
Blank & 0.01 & 0.011 & \\
\hline - Certified Value (mg/Kg): & 70.2 \\
- Advisory Range: & $44.9-100$ \\
- Digestions analyzed with a Leernan Labs PS 200 \\
merany analyzer
\end{tabular}

Table 12

Method 7471 water bath digestion

Replicate Experimental Standard Percent Recovery Number Value (mg/Kg) Deviation of Certified Value

\begin{tabular}{cccc}
\hline 1 & 69.6 & 5.77 & $99 \%$ \\
2 & 67.7 & 2.52 & $96 \%$ \\
3 & 69.8 & 3.58 & $99 \%$ \\
4 & 73.6 & 5.37 & $105 \%$ \\
5 & 72.1 & 4.67 & $103 \%$ \\
Average & 70.6 & 2.32 & $101 \%$ \\
Blank & -0.01 & 0.016 & \\
\hline - Certified Value (mg/Kg): & 70.2 \\
- Advisory Range: & $44.9-100$ \\
- Digestions analyzed with a Leeman Labs PS 200 \\
merary analyzer
\end{tabular}




\section{Mercury in Oil Results}

(Purchased from Conostan (Lot \# 13015))

\section{Oak Ridge National Laboratory}

Table 13

Method 3051 temperature controlled digestion Milestone MEGA 1200 microwave

Replicate Experimental Standard Percent Recovery Number Value (mg/Kg) Deviation of Certified Value

\begin{tabular}{cccc}
\hline 1 & 108.2 & 0.26 & $108 \%$ \\
2 & 104.3 & 0.22 & $104 \%$ \\
3 & 105.5 & 0.06 & $106 \%$ \\
4 & 105.4 & 0.33 & $105 \%$ \\
5 & 106.4 & 0.17 & $106 \%$ \\
Average & 106.0 & 1.48 & $106 \%$ \\
Blank & 0.00 & 0.000 & \\
\hline - Certified Value (mg/Kg): & $100 \quad H-10$ \\
- Digestions analyzed with a TJA QS-1 mercury \\
analyzer
\end{tabular}

Argonne National Laboratory

Table 15

Method 3051 temp/press controlled digestion CEMMDS 2100 microwave

Replicate Experimental Standard Percent Recovery Number Value (mg/Kg) Deviation of Certified Value

\begin{tabular}{|c|c|c|c|}
\hline \multicolumn{4}{|c|}{ CEMMDS 2100 microwave } \\
\hline $\begin{array}{l}\text { Replicate } \\
\text { Number }\end{array}$ & $\begin{array}{l}\text { Experimental } \\
\text { Value (mg/Kg) }\end{array}$ & $\begin{array}{l}\text { Standard } \\
\text { Deviation }\end{array}$ & $\begin{array}{l}\text { Percent Recovery } \\
\text { of Certified Value }\end{array}$ \\
\hline 1 & 98.9 & 8.03 & $99 \%$ \\
\hline 2 & 99.0 & 7.80 & $99 \%$ \\
\hline 3 & 97.8 & 8.04 & $98 \%$ \\
\hline 4 & 97.2 & 6.79 & $97 \%$ \\
\hline 5 & 101.0 & 8.79 & $101 \%$ \\
\hline Average & 98.8 & 1.45 & $99 \%$ \\
\hline Blank & 0.04 & 0.031 & \\
\hline $\begin{array}{l}\text { - Certified } \\
\text { - Digestion } \\
\text { meraury a }\end{array}$ & $\begin{array}{l}\text { Value }(\mathrm{mg} / \mathrm{Kg}) \\
\text { s analyzed with a } \\
\text { nalyzer }\end{array}$ & $\begin{array}{c}100 \\
\text { Leeman } L\end{array}$ & $\begin{array}{l}+1-10 \\
\propto \operatorname{PS} 200\end{array}$ \\
\hline
\end{tabular}

Table 14

Method 3051 pressure controlled digestion using a CEMMDS81 microwave

Replicate Experimental Standard Peroent Recovery Number Value $(\mathrm{mg} / \mathrm{Kg})$ Deviation of Certified Value

\begin{tabular}{cccc}
\hline 1 & 113.0 & 0.15 & $113 \%$ \\
2 & 100.3 & 0.09 & $100 \%$ \\
3 & 114.8 & 0.17 & $115 \%$ \\
4 & 115.8 & 0.00 & $116 \%$ \\
5 & 108.0 & 0.10 & $108 \%$ \\
Average & 110.4 & 6.38 & $110 \%$ \\
Blank & 0.00 & 0.000 & \\
\hline - Certified Value (mg/Kg): & $100 \quad$ H- 10 \\
- Digestions analyzed with a TJA QS-1 mercury \\
analyzer
\end{tabular}

Table 16 Method 7471 water bath digestion

Replicate Experimental Standard Percent Recovery Number Value $(\mathrm{mg} / \mathrm{Kg})$ Deviation of Certified Value

\begin{tabular}{cccc}
\hline 1 & 98.0 & 6.98 & $98 \%$ \\
2 & 95.9 & 5.26 & $96 \%$ \\
3 & 94.9 & 6.17 & $95 \%$ \\
4 & 95.6 & 5.84 & $96 \%$ \\
5 & 94.2 & 5.90 & $94 \%$ \\
Average & 95.7 & 1.42 & $96 \%$ \\
Blank & -0.01 & 0.032 & \\
\hline - Certified Value (mg/Kg): & $100 \quad+1-10$ \\
- Digestions analyzed with a Loeman Labs PS 200 \\
merary analyzer
\end{tabular}




\section{REFERENCES}

1. U.S. Environmental Protection Agency (EPA) 1994. Test Methods for Evaluating Solid Waste, SW-846, 3rd ed., Office of Solid Waste and Emergency Response, Washington, D.C., November 1986; Update II, September 1994.

2. U.S. Department of Energy. Transuranic Waste Characterization Quality Assurance Program Plan, CAO-94-1010, Revision 0, Carlsbad Area Office, Carlsbad, New Mexico, April 1995.

\section{DISTRIBUTION}

1-2. Central Research Library

3. J. Connolly, INEL, P. O. Box 1625, Idaho Falls, Idaho 83415-39104

4. M. Connolly, INEL, P. O. Box 1625, Idaho Falls, Idaho 83415-2424

5-7. A. A. Essling, Analytical Chemistry Laboratory, Argonne National Laboratory, 9700 South Cass Avenue, Argonne, Illinois 60439

8-12. J. M. Giaquinto

13-17. J. M. Keller

18-19. Laboratory Records Department - RC

20-21. Office of Scientific and Technical Information, P. O. Box 62, Oak Ridge, Tennessee 37831-8600

22. M. L. Poutsma

23. J. R. Stokely

24. J. Suermann, U. S. DOE, 101 West Greene Street, Carlsbad, New Mexico 88220 